\title{
Commentary
}

\section{National Policies and the International Student: The Arizona Immigration Law}

\author{
Chea Kagnarith \\ Australian Centre for Education, Cambodia \\ Kagnarith.Chea@acecambodia.org
}

The process of globalization has had far-reaching effects over the last decades. Due to crucial breakthroughs in science and technology, it is now possible for one person to talk to another in a different country in seconds, and news can penetrate every corner of the globe in just minutes. In addition, Friedman (2006), The New York Times columnist, suggests that the business world is now "flat;" traditional barriers restricting entry into the global marketplace no longer exist. Today, entrepreneurs or enterprises can compete or collaborate on the global stage, and the advantages of location are melting away. Considering higher education, Gürüz (2008) discusses how the recent mass mobility of an estimated 2.5 million international students takes place and contributes to the global knowledge economy. Healey (2008) also discusses the concept of globalization in terms of higher education, which he refers to as the "internationalization" of higher education, with particular emphasis on how institutions in developed countries have taken advantage of this phenomenon. Specifically, higher education institutions in some developed countries have strategically profited from the emerging pool of students from developing countries who are increasingly entering the global education market. In England and New Zealand, international enrolment accounts for approximately $13 \%$ and $14 \%$ of the student body, respectively (Healey, 2008). Countries with a low population and a strong demand for skilled workers find such internationalization beneficial to meet the skilled labor need in addition to earning tuition fees from international students (Bowen, 2010; Hartcher, 2010).

Nevertheless, the increased movement of peoples on a global scale has not occurred without challenges. One drawback of this internationalization of mobility is the issue of migrant employment. According to Hartwich (2010), for example, England has made an attempt to cap non-European immigration to deal with this problem. The argument is that employment opportunities for citizens should be preserved. However, resulting caps to immigration may affect the number of international students, and thus are criticized because such limits may be detrimental to some universities, which are already suffering from budget cuts. Australia is a case in point; stricter immigration rules have resulted in an unexpected decrease of 100,000 international students in 2010 (International Education Association of Australia, 2010). Within the education sector, institutions may welcome international students and the financial windfall they represent, yet the impact on the societies in which such students may represent significant numbers cannot be overlooked (Hartcher, 2010; Lee \& Rice, 2007; Sugimura, 2008; Valentine,

Language Education in Asia, 2010, 1(1), 258-261. http://dx.doi.org/10.5746/LEiA/10/V1/A21/Chea 
2010). Even considering the stressors involved for all stakeholders, it seems likely that the international mobility of students will increase in the future.

I recently had the opportunity to join the Fulbright International Educational Exchange Program, and thus became an international student. I have been back in my home country, Cambodia, for about four months now. I am still missing my life, my friends, and my school in the United States, where I spent two years earning my Master's degree in linguistics. Winning a place in and participating in the Fulbright program was a once-in-lifetime experience. Having the opportunity to study was one thing, but having the chance to explore life in the United States was quite another. I was in the U.S. during a few of its historical moments. I was there when the first African American was elected as the President and when a devastating economic crisis began. In addition, I spent my two years as an international student at Arizona State University in Arizona, the state where the toughest new immigration law was proposed and passed. In this article, my comments will focus on the impact of this new immigration law from the perspective of an international student.

The United States, with a population of about 307 million people, has the world's largest economy and is one of the richest countries in the world ("United States," n.d.). According to Gaynor and Schwartz (2010), however, illegal immigration is one of the biggest problems in the U.S., although the recent healthcare overhaul and the economic downturn seem to distract attention from the issue. Nowhere in the U.S. has the attitude toward the estimated 12 million illegal immigrants been sterner than in Arizona, where roughly one-third of the population of approximately 6.5 million were born outside of the U.S. ("Arizona immigration law," 2010; Albrecht, 2008; Seper, 2010) and where it is estimated that approximately 450,000 illegal immigrants reside (Seper, 2010). To contend with illegal immigration, Arizona adopted Senate Bill (SB) 1070, which requires all immigrants to carry IDs with them at all times and in so doing, provides a gray area which could lead to racial profiling, as police have the authority to stop any "suspicious" person to ask for an ID ("The new Arizona," 2010, para. 6).

SB1070 was signed into law by Governor Jan Brewer on 23 April, 2010 (Barrón, 2010). The bill is a controversial topic, not only for the public in general, but also for international students. The Fulbright fellows in Arizona, myself included, were worried by this law, which we felt gave too much privilege to the police. We were concerned about being subject to racial profiling by the police, even after Governor Brewer confirmed that racial profiling was illegal and would not be tolerated ("Statement by Governor," 2010). When I first arrived in Arizona, I felt warm and respectful toward the police. Coming from a developing country, I appreciated the sense of security they provided. After the law was signed, I started to have different feelings: I felt a bit terrified and nervous whenever I heard a police siren or saw a police car. Although we carried the required IDs, it was difficult to know what would happen if we were stopped by the police. There could be many possible outcomes. The police might believe our alien documents and passports were forged and put us in jail first. Or the police might arrest us because they perceive us as suspicious: while it was claimed that the police would be trained to look only for "suspicious people" (Archibold, 2010; Barrón, 2010; "The new Arizona," 2010), in the end, there were no apparent criteria as to how to determine whether someone was "suspicious" or not. No matter how much training was provided, the determination of who was suspicious could be highly subjective (Campo-Flores, 2010). As part of the minority community, we felt uncertain and concerned as it seemed likely that we could be stopped by the police and potentially be questioned or arrested.

I learned about a demonstration against the new law at the State Capitol Building. I took part in the demonstration because like others attending, I was against the law. At the State Capitol, the 
scene was calm. Although the majority of the demonstrators were against the new law, there were a few who supported it, which I appreciated in terms of their freedom of expression. This is a good aspect about the United States: you can always find people who really support their opinions with actions, no matter what the rest are thinking or doing. It was my first genuine experience with democracy in the U.S.

I understood Arizona's urgency to deal with illegal immigration. However, the effect of this law goes beyond illegal immigration. The perceived possibility of racial profiling might prompt international students to avoid opting for Arizona or even perhaps the U.S. If significant numbers of international students seek higher education destination alternatives to the U.S., this could eventually jeopardize the status of the U.S. as a world leader in science and technology, which is made possible through collaborations between scholars from different countries. As Stewart (2010) puts it, the presence of international students and researchers could drive Americans to be more competitive in the world market. This situation is not unique to the U.S., and must be addressed in many developed countries, many of which are popular destinations for international students. Immigration policies such as SB1070 can obstruct the mobility of international students, researchers, and scholars, opposite to governments' efforts in supporting exchange programs such as the Fulbright scholarship, with negative consequences for the global flow of knowledge. Both international students and host countries can benefit from the increasing numbers of students seeking educational opportunities aboard, but both sides must strive to adapt to the unique challenges that such increased mobility presents.

\section{Biodata}

Chea Kagnarith has received his Master of Arts in Linguistics from Arizona State University. He has been involved in the ELT arena for more than 6 years with particular interests in ELT management and Universal Grammar. He is now employed as a branch manager at the Australian Centre for Education.

\section{References}

Albrecht, D. E. (2008). The state of Arizona. Retrieved from http://www.wrdc.usu.edu/files/uploads/Population/Arizona_WEB.pdf

Archibold, R. C. (2010, July). Arizona challenge does not focus on profiling. The New York Times. Retrieved from http://www.nytimes.com/2010/07/08/us/08immig.html

Arizona immigration law set to come in amid protests. (2010, July 28). BBC. Retrieved from http://www.bbc.co.uk/news/world-us-canada-10791871

Barrón, A. (2010, April 23). Gov. Brewer signs controversial immigration bill SB1070. Retrieved from http://www.azfamily.com/news/local/Brewer-signs-immigration-enforcement-bill91939104.html

Bowen, C. (2010, February 8). Changes to Australia's skilled migration program. Retrieved from http://www.minister.immi.gov.au/media/speeches/2010/ce100208.htm

Campo-Flores, A. (2010, April 27). Will Arizona's new immigration law lead to racial profiling? Newsweek. Retrieved from http://www.newsweek.com/2010/04/26/will-arizona-snew-immigration-law-lead-to-racial-profiling.html

Friedman, T. (2006). The world is flat. New York, NY: Farrar, Straus and Giroux.

Gaynor, T., \& Schwartz, D. (2010, April 19). Arizona passes tough illegal immigration law. Reuters. Retrieved from http://www.reuters.com/article/idUSTRE63I6TU20100419

Gürüz, K. (2008). Higher education and international student mobility in the global knowledge economy. Albany, NY: SUNY Press. 
Hartcher, P. (2010, April 13). When Indian students suffer, Australia risks being scarred for life. The Sydney Morning Herald. Retrieved from http://www.smh.com.au/opinion/politics/when-indian-students-suffer-australia-risksbeing-scarred-for-life-20100412-s3zh.html

Hartwich, V. (2010, October 5). How the immigration cap damages higher education in the UK, openDemocracy. Retrieved from http://www.opendemocracy.net/ourkingdom/val\%C3\%A9rie-hartwich/howimmigration-cap-damages-higher-education-in-uk

Healey, N. M. (2008) Is higher education really 'internationalising'? Higher Education, 55(3), 333-355. http://dx.doi.org/10.1007/s10734-007-9058-4

International Education Association of Australia (IEAA). (2010, June 7). International education faces a 10 year recovery - media release. Retrieved from http://www.ieaa.org.au/NewsArticles/NewsArticle.asp?articleNo=62

Lee, J. J., \& Rice, C. (2007). Welcome to America? International student perceptions of discrimination. Higher Education, 53(3), 381-409. http://dx.doi.org/10.1007/s10734005-4508-3

Seper, J. (2010, May 3). Mexico's illegals laws tougher than Arizona's. The Washington Times. Retrieved from http://www.washingtontimes.com/news/2010/may/03/mexicos-illegalslaws-tougher-than-arizonas/?page $=1$

Statement by Governor Jan Brewer. (2010, April 30). Retrieved from http://www.azgovernor.gov/dms/upload/PR_043010_StatementGovBrewer.pdf

Stewart, H. (2010, March 26). International education is key to making immigration reform work for America, NAFSA (National Association of Foreign Student Advisers):

Association of International Educators. Retrieved from http://blog.nafsa.org/2010/03/26/international-education-is-key-to-making-immigrationreform-work-for-america-2/

Sugimura, M. (2008, September). International student mobility and Asian higher education: Framework for global network. Paper presented at the Asia-Pacific Sub-regional Preparatory Conference for the 2009 World Conference on Higher Education, Macau, PR China.

The new Arizona immigration law "says that any police officer can stop anyone who appears to them to be reasonably suspicious of being an undocumented person." (2010, April 26). Retrieved from http://www.politifact.com/truth-o-meter/statements/2010/apr/28/alfredogutierrez/arizona-immigration-law-allows-police-question-any/

United States. (n.d.). In Encyclopædia Britannica online. Retrieved from http://www.britannica.com/EBchecked/topic/616563/United-States

Valentine, L. (2010, January). Truth behind Indian student attacks in Australia. Retrieved from Embrace Australia: http://www.embraceaustralia.com/truth-behind-indian-studentattacks-in-australia-5823.htm 